\title{
Association between Vitamin D Receptor Gene Polymorphisms and Anemic Patients
}

\author{
Fathy A. Yassin', Noha M. Said ${ }^{2}$, and Doha Tarek ${ }^{2}$ \\ ${ }^{1}$ Chemistry Department, Faculty of science, Zagazig University, Zagazig, Egypt. \\ ${ }^{2}$ Biochemistry Division, Chemistry Department, Faculty of science, Zagazig University, Zagazig, Egypt
}

\begin{tabular}{l}
\hline A R T I C L E I N F O \\
\hline VDR, Gene polymorphism \\
Anemia , Double ARMS PCR
\end{tabular}

\begin{abstract}
$\begin{array}{llllll}\text { A B S T R A C T } & & & & \\ \text { Background: Vitamin } & \text { D endocrine } & \text { system controls calcium }\end{array}$ homeostasis and bone metabolism in addition to cellular proliferation and differentiation. Several new studies have publicized that calcitriol which represent the active form of vitamin $\mathrm{D}$ is involved in hematopoiesis. Furthermore, vitamin D receptor (VDR) mediates vitamin D activity. Therefore VDR gene has been proposed as one of the candidate genes for anemia. Aim: Study relationship between low hemoglobin level as the first cause for anemia and (ApaI and TaqI) polymorphisms of VDR gene in terms of genotype and allele in unrelated normal healthy individuals without chronic kidney diseases of Egyptian population. Subjects and methods: A case-control study including 130 unrelated Egyptian donors (81 cases and 49 controls) deprived of chronic kidney diseases was designed to check the relationship between VDR gene polymorphisms and low
\end{abstract} hemoglobin level. Two SNPs [ApaI (rs7975232) and TaqI (rs731236)] were typed by polymerase chain reaction (PCR) method.

Results: Analyses using codominant, dominant, and recessive models failed to reveal any significant association between both (ApaI and TaqI) polymorphisms and anemia in terms of genotype and allele for the covariates (age, blood hemoglobin level, age at menopause (For women), educational level, ethnicity, medical history, serum ferritin and iron). Conclusion: VDR gene polymorphisms have no effect on anemia in Egyptian population without chronic kidney disease. Further study on the association between polymorphisms of VDR gene and anemia, a potential study design, use of large number of samples, and additional markers would improve the validity and reliability of findings.

CC 2017 Publisher All rights reserved. 


\section{INTRODUCTION}

Healthy skeletal and neuromuscular tissues depend on vitamin $\mathrm{D}$ due to its important role in blood calcium and phosphorus balance ${ }^{[1]}$. Humans can acquire vitamin D from diet and through photosynthesis with the direct contact with sunrays. Vitamin D is converted in the liver to $(25(\mathrm{OH}) \mathrm{D})$, then to its active form 1,25-dihydroxy vitamin $D$ in the kidney ${ }^{[2]}$. In recent times, it is shown that vitamin D has been related to epithelial functions, metabolic regulation, immunity, and chronic diseases [3]. Besides, several scientific studies suggested the vitamin $D$ responsibility for normal erythropoiesis ${ }^{[4]}$. The significant connection between the Vitamin D insufficiency and anemia has been disclosed ${ }^{[5]}$. The effects of this molecule are essentially exerted through its cognate, the vitamin D receptor (VDR) ${ }^{[6]}$. Moreover, there was a correlation between VDR polymorphisms and vitamin $\mathrm{D}_{3}$ level [7]. Therefore, VDR gene has been suggested for hemoglobin low level. Anemia is one of the most common and well-known disorder in the world. It is a global public health problem in both developed and non-developed countries. World Health Organization (WHO) was defined anemia as a disorder in which the oxygen-carrying hemoglobin or the number of red blood cells is inadequate to meet physiological needs. With $24.8 \%$, anemia affects nearly $1 / 4$ of the global population, commonly in pregnant and non-pregnant women and in preschoolaged children ${ }^{[8]}$. There is a variety of causes that can induce the decrease of hemoglobin level and so anemia such as inadequate iron intake, hemolysis, chronic blood loss, malabsorption, chronic disease, or a combination of these ${ }^{[9-11]}$. While several studies focus on the relation of VDR with anemia in hemodialysis and chronic kidney patients, there is global paucity of studies investigating the effect of VDR polymorphism on blood hemoglobin $(\mathrm{Hb})$ levels in population without kidney diseases. At present, ApaI; rs7975232, TaqI; rs731236, BsmI; rs1544410, and FokI; rs10735810 are the most SNPs in the VDR gene that have been studied [12, 13]. There are several methods labeled for the rapid detection of SNPs such as PCR method. In most studies, VDR genotyping has been operated using polymerase chain reactionrestriction fragment length polymorphism (PCR-RFLP) technique. This procedure is bulky, consume time, and their results are sometimes difficult to understand. One of the progresses in DNA amplification technology was allele-specific oligonucleotide PCR or the amplification refractory mutation system (ARMS). This technique is a specific and rapid test that was firstly designed by Newton in 1989 to detect known single-base substitutions or insertions. In ARMS-PCR, a single PCR tube contains 2 pairs of primers that can amplify both normal and mutant alleles at the same time and can allow amplification of an internal DNA control [14-16]. Furthermore, in the double ARMS-PCR two allele specific primers can be used simultaneously during PCR to separate a sequence of interest from two or more closely related sequences. While the genetic profile of VDR and its association with anemia is still under discussion, in this study, we examined the relationship between hemoglobin low level as the first cause for anemia and the VDR gene polymorphisms (ApaI and TaqI) in terms of genotype and allele in Egyptian population.

\section{SUBJECTS AND METHODS:}

\section{Subjects and Measurements}


A case-control study including 130 unrelated normal healthy individuals without kidney diseases of Egyptian donors (81 cases and 49 controls) was designed to study the link between VDR gene polymorphisms and low hemoglobin level as the first cause for anemia. Data were collected on current age, age at menopause (For women), ethnicity, educational level, and medical history. Blood samples were collected from medical laboratories and hospitals from October 2013 until March 2014. Blood samples were collected on EDTA from donors and DNA was separated from white blood cells by Blood DNA Preparation Kit (Jena Bioscience $\mathrm{GmbH}$, Germany). Both genomic DNA and blood serum were stored at $-20^{\circ} \mathrm{C}$ until further processing. Concentration of blood hemoglobin $(\mathrm{Hb})$ was measured using colorimetric end point cyanmethemoglobin method by Vitro Scient kit (MDSS GmbH, Germany), serum iron was measured using colorimetric method by Biodiagnostic kit (Giza, Egypt), and serum ferritin (F) was measured using solid phase enzyme-linked immunosorbent assay by Immunospec Ferritin Quantitative Test Kit (Owensmouth Ave, Canoga Park). Anemia was defined as a hemoglobin concentration $<13.0 \mathrm{~g} / \mathrm{dl}$ for males, $<12.0 \mathrm{~g} / \mathrm{dl}$ for females, and $<11.5 \mathrm{~g} / \mathrm{dl}$ for children and iron deficiency as a serum ferritin $<15$ $\mathrm{ng} / \mathrm{mL}$, and serum iron $<7.3 \mathrm{Mmol} / \mathrm{L}$.

\section{Genotyping}

Vitamin D receptor genotypes were determined with double ARMS-PCR method. In this method, each sample was done with 4 PCR reactions with final volume of $25 \mu \mathrm{l}$ for each reaction. Each reaction composed of $5 \mu \mathrm{l}$ of DNA, $10 \mu \mathrm{l}$ of master mix (Buffer, dNTP mix, $\mathrm{MgCl} 2$, Taq Polymerase) and $5 \mu \mathrm{l}$ of one of 4 diluted primers mixtures. In double ARMS-PCR method, we prepare 4 primers mixtures for 4 PCR reactions. Each primer mixture composed of two primers (A, a, T and t) Table (1). Amplification conditions were: $96^{\circ} \mathrm{C} / 1 \mathrm{~min}$; 5 cycles $\left(95^{\circ} \mathrm{C} / 25 \mathrm{sec}\right.$, $61^{\circ} \mathrm{C} / 40 \mathrm{sec}, \quad 72^{\circ} \mathrm{C} / 42 \mathrm{sec}$.); 21 cycle (96 ${ }^{\circ} \mathrm{C} / 25 \mathrm{sec}, 65^{\circ} \mathrm{C} / 50 \mathrm{sec}, 61^{\circ} \mathrm{C} / 45 \mathrm{sec}$.); 4 cycles $\quad\left(96^{\circ} \mathrm{C} / 25 \mathrm{sec}, \quad 55^{\circ} \mathrm{C} / 60 \mathrm{sec}\right.$, $72^{\circ} \mathrm{C} / 120 \mathrm{sec}$.); $72^{\circ} \mathrm{C} / 5 \mathrm{~min}$. PCR products have been evaluated by $2 \%$ agarose gel (Sigma) stained with ethydium bromide under ultraviolet light. For each sample one or two PCR reaction as maximum will give band at $117 \mathrm{bp}$. Each sample will give one of the four possible haplotypes (AATT; aatt; AAtt, aaTT) for the two polymorphisms (ApaI, and TaqI).

\section{Statistical analysis}

All the statistics was done with "SPSS" software version 16.0. Unpaired Student's $t$-test was utilized to evaluate continuous clinical data, while chi-square test was utilized to evaluate categorical variables between patients and control. Data were expressed as mean \pm standard error of mean (SE) (continuous variables) or as the number and percent of patients (categorical variables). The genotype frequencies in controls and patients were evaluated for (HWE) with (Exact Fisher's method) when excepted cell frequency is less than 5. Armitage's trend test and Allele freq. difference test is used to test the significance in difference between genotypes and alleles frequencies distribution respectively. Logistic regression was performed under three genotypic models (Co-dominant, dominant and recessive). The power of connection was expected by (OR), with 95\% (95\% $\mathrm{CI})$. The statistical significance was confirmed for $\mathrm{p}<0.05$. While (ANOVA) was done to evaluate the link between the polymorphism at both sites and quantitative hematological parameters were evaluated using the (GLM) procedure of the Statistical Package for Social Sciences version 22.0.

\section{RESULTS:}




\section{Subjects characters}

Demographic and clinical characteristics of subjects in anemic and control groups are shown in Table (2). No significant differences were found between these two groups in mean age $(\mathrm{P}>0.05)$ or serum concentration of ferritin $(\mathrm{P}>0.05)$ but there was a significant difference between them in gender, hemoglobin, and serum concentration of iron $(\mathrm{p}<0.05)$.

\section{Distribution of ApaI and TaqI VDR gene polymorphisms}

Genotypes and alleles distribution for both VDR sites are shown in Table (3). The most frequent genotypes of the ApaI and TaqI polymorphisms were GT and TC respectively. No significant difference was observed between cases $(p>0.05)$ and control groups $(p>0.05)$ in the genotypic frequencies of ApaI SNP thus both allele and genotype were in HWE. But in case of TaqI SNP it was revealed that both cases and control groups were deviated from Hardy-Weinberg equilibrium in the distribution of genotype frequencies $(\mathrm{p}<0.05)$. Armitage trend test and Allele frequency difference test show that both genotype and allele distributions of ApaI and TaqI SNPs have no significant between cases and control groups $(\mathrm{p}>0.05)$ Tables (3-5). The results of the association between anemia and the VDR SNPs are summarized in Table (5). Analyses using codominant, dominant, and recessive models failed to reveal any association between the ApaI polymorphism and anemia. Also no evidence of significant association between TaqI polymorphism and anemia was observed under codominant, dominant, and recessive models (Table 5).

\section{Pearson Correlation}

A significant negative correlation between $\mathrm{Hb}$ and serum level of ferritin was found $(\mathrm{p}<0.05)$. But neither $\mathrm{Hb}$ nor ferritin has significant correlation with iron $(\mathrm{p}>0.05)$

Table (6)

\section{DISCUSSION:}

The goal of this work was to find out if common VDR polymorphisms cause low hemoglobin level as the first cause of anemia in a random Egyptian population without chronic kidney disease. VDRs belong to a family of transacting transcriptional regulatory factors and have a sequence similarity to thyroid hormone and steroid receptors. It is expressed in at least 37 tissues such as pancreatic $\beta$ cells, cardiovascular cells, muscle cells, lung, and brain ${ }^{[17,18]}$. The VDR is mediating most biological activities of vitamin $\mathrm{D}$. VDR binds the active form of vitamin D (calcitriol) and then modulates several physiological systems: neural, immune, endocrine, apoptosis, calcium and phosphorous homeostasis, and cell differentiation ${ }^{[19,20]}$. The polymorphism of the VDR gene could lead to significant receptor dysfunction and then related to health outcomes including low bone mineral density, autoimmunity, infections, cardiovascular disease and cancers. In this study, we analyzed ApaI; rs7975232 and TaqI; rs731236 SNPs frequencies of VDR gene with low hemoglobin level as the first cause for anemia in a hospital-based casecontrol design with 81 Egyptian patients with anemia and 49 healthy controls. Analysis of our results revealed that no connection was observed between any of the polymorphisms and threat of anemia in this Egyptian population in terms of genotype or allele frequencies for the VDR SNPs examined. A similar finding was observed by T. Binh, et al. ${ }^{[21]}$ as the allele and genotype frequencies for both TaqI and ApaI SNPs showed no significant difference between patients and controls. The hypothesis that VDR may be implicated in pathogenesis of anemia derives from the observation that vitamin D deficiency had significant association with anemia, and calcitriol, the active form of vitamin D, was involved in 
hematopoiesis5 ${ }^{[5,22]}$. Our results do not support this hypothesis in Egyptian population without chronic kidney disease. We have reported a lack of statistical significance for such an association in terms of genotype and allele under codominant, dominant, and recessive models for the covariates (age, blood hemoglobin level, age at menopause (For women), educational level, ethnicity, medical history, serum ferritin and iron). Several studies supported the link between VDR gene polymorphism and anemia in hemodialysis and chronic kidney patients. According to Sehsuvar Ertu“rk, BsmI polymorphism may have a role in the management of anemia in hemodialysis patients. The BB genotype is one of the strongest independent predictors for both lower $\mathrm{Hb}$ level and greater erythropoietin (EPO) need ${ }^{[23]}$. Furthermore Jessica Cusato proved the role of VDR gene polymorphisms in the ribavirin-induced anemia in HCV-patients at 2 and 4 weeks of medication ${ }^{[24]}$. Moreover, large-scale studies indicate that vitamin D insufficiency was associated with more risk for anemia incidence in general population. It is well recogized that VDR gene polymorphisms are linked with the risk of several diseases other than anemia such as diabetes mellitus ${ }^{[25,26]}$, hepatitis B virus [27], cancers [28], etc. In 2009, Panierakis et al. ${ }^{[25]}$ published a report that finding a relationship between ApaI and TaqI polymorphisms and type 1 diabetes mellitus in Greece population. One year later, a paper of Huang et al. ${ }^{\text {[27] }}$ showed the connection between the ApaI and TaqI polymorphisms and an more risk for hepatitis B virus incidence in Taiwan. Moreover, Reimers et al. ${ }^{[28]}$ was studying the relationship between VDR gene polymorphisms and breast cancer risk in New York in 2015.

\section{CONCLUSION:}

Our study shows characteristics of ApaI and TaqI SNPs of VDR gene in terms of genotype and allele, and suggests no significant association between the individual VDR gene and low hemoglobin level in normal healthy Egyptian population. Therefore, it is early to suggest that VDR gene polymorphism can induce anemia. For additional study on the association between VDR and low hemoglobin level, larger sample size, prospective study design, and additional indicators must be used to improve the findings.

\section{REFERENCES:}

[1] Meguro S, Tomita M, Katsuki T, Kato $\mathrm{K}$, Oh H, Ainai A, Ito R, Takeda S, Kawai T, Atsumi Y, Itoh H, (2011): Plasma 25hydroxyvitamin $\mathrm{d}$ is independently associated with hemoglobin concentration in male subjects with type 2 diabetes mellitus. International journal of endocrinology; 2011.

[2] Tian J, Liu Y, Williams LA, de Zeeuw D, (2007): Potential role of active vitamin $\mathrm{D}$ in retarding the progression of chronic kidney disease. Nephrology Dialysis Transplantation; 22:321-328.

[3] Lee P, (2011): Vitamin D, metabolism and deficiency in critical illness. Best Practice \& Research: Clinical Endocrinology \& Metabolism; 25:769781.

[4] Kersey M, Chi M, Cutts DB, (2011): Anaemia, lead poisoning and vitamin D deficiency in low-income children: do current screening recommendations match the burden of illness? Public health nutrition; 14(8):1424-1428.

[5] Sim JJ, Lac PT, Liu IL, Meguerditchian SO, Kumar VA, Kujubu DA, Rasgon SA, (2010): Vitamin D deficiency and anemia: a cross-sectional study. Annals of hematology; 89(5):447452.

[6] Swamy N, Xu W, Paz N, Hsieh JC, Haussler MR, Maalouf GJ, Mohr SC, Ray R, (2000): Molecular modeling, affinity labeling, and site-directed mutagenesis define the key points of interaction between the ligand-binding domain of the vitamin D nuclear receptor and 1 alpha,25- 
dihydroxyvitamin D3. Biochemistry; 39(40):12162-12171.

[7] Bhanushali AA, Lajpal N, Kulkarni SS, Chavan SS, Bagadi SS, Das BR, (2009): Frequency of fokI and taqI polymorphism of vitamin D receptor gene in Indian population and its association with 25hydroxyvitamin D levels. Indian journal of human genetics; 15(3):108-113.

[8] McLean E, Cogswell M, Egli I, Wojdyla D, de Benoist B, (2009): Worldwide prevalence of anaemia, WHO Vitamin and Mineral Nutrition Information System, 1993-2005. Public health nutrition; 12(4):444-454.

[9] Weiss G, Goodnough LT, (2005): Anemia of chronic disease. New England Journal of Medicine; 352(10):1011-1023. [10] Annibale B, Marignani M, Monarca B, Antonelli G, Marcheggiano A, Martino G, Mandelli F, Caprilli R, Delle Fave G, (1999): Reversal of iron deficiency anemia after Helicobacter pylori eradication in patients with asymptomatic gastritis. Annals of internal medicine.; 131(9):668672.

[11] Gasche C, Lomer MC, Cavill I, Weiss G, (2004): Iron, anaemia, and inflammatory bowel diseases. Gut; 53:1190-1197.

[12] Uitterlinden, AG, Fang, Y, Van Meurs, JB, Pols HA, van Leeuwen JP, (2004): Genetics and biology of vitamin D receptor polymorphisms. Gene; 338(2):143-156.

[13] Qin WH, Wang HX, Qiu JL, Huang XB, Huang Y, Wu NR, Liang HS, (2014): A meta-analysis of association of vitamin $\mathrm{D}$ receptor BsmI gene polymorphism with the risk of type 1 diabetes mellitus. Journal of Receptors and Signal Transduction; 34(5):372-377.

[14] Old JM, Varawalla NY, Weatherall DJ, (1990): Rapid detection and prenatal diagnosis of beta-thalassaemia: studies in Indian and Cypriot populations in the UK. Lancet; 336(8719):834-837.

[15] Vannucchi AM, Pancrazzi A, Bogani C, Antonioli E, Guglielmelli P, (2006): A quantitative assay for JAK2 (V617F) mutation in myeloproliferative disorders by ARMS-PCR and capillary electrophoresis. Leukemia; 20(6):10551060.

[16] Wang YZ, Zhu Z, Zhang HY, Zhu MZ, Xu X, Chen CH, Liu LG, (2014): Detection of hepatitis $\mathrm{B}$ virus A1762T/G1764A mutant by amplification refractory mutation system. Brazilian Journal of Infectious Diseases; 18(3):261265.

[17] Bouillon R, Okamura WH, Norman AW, (1995): $\quad$ Structure-function relationships in the vitamin $\mathrm{D}$ endocrine system. Endocrine reviews; 16(2):200257.

[18] Menezes RJ, Cheney RT, Husain A, Tretiakova M, Loewen G, Johnson CS, Jayaprakash V, Moysich KB, Salgia R, Reid ME, (2008): Vitamin D receptor expression in normal, premalignant, and malignant human lung tissue. Cancer Epidemiology and Prevention Biomarkers; 17(5):1104-1110.

[19] Plum LA, DeLuca HF, (2010): Vitamin D, disease and therapeutic opportunities. Nature reviews Drug discovery; 9(12):941-955.

[20] Bikle DD. (2011): Vitamin D regulation of immune function. Vitamins and hormones; 86:1-21.

[21] Binh TQ, Hienc VT, Khan NC Lam NT, Mar LB, Nakamori M, Yamamoto Sh, (2010): Relationship between vitamin D receptor gene polymorphisms and anemia in postmenopausal Vietnamese women. Asian Biomedicine; 4(6):869-875.

[22] Bunce CM, Brown G, Hewison M. (1997): Vitamin D and hematopoiesis. Trends in Endocrinology \& Metabolism; 8(6): 245-251.

[23] Ertürk S, Kutlay S, Karabulut HG, Keven K, Nergizoglu G, Ates K, Bokesoy I, Duman N, (2002): The impact of vitamin $\mathrm{D}$ receptor genotype on the management of anemia in hemodialysis patients. American journal of kidney diseases; 40(4):816-823.

[24] Cusato J, Allegra S, Boglione L, De Nicolò A, Cariti G, Di Perri G, D'Avolio 
A, (2015): VDR gene polymorphisms impact on anemia at 2 weeks of anti-HCV therapy: a possible mechanism for early RBV-induced anemia. Pharmacogenetics and genomics; 25(4):164-172.

[25] Panierakis C, Goulielmos G, Mamoulakis D, Petraki E, Papavasiliou E, Galanakis E, (2009): Vitamin D receptor gene polymorphisms and susceptibility to type 1 diabetes in Crete, Greece. Clinical immunology; 133(2):276-281.

[26] Al-Daghri NM, Al-Attas O, Alokail MS, Alkharfy KM, Draz HM, Agliardi C, Mohammed AK, Guerini FR, Clerici M, (2012): Vitamin D Receptor Gene Polymorphisms and HLA DRB $1 * 04$ Cosegregation in Saudi Type 2 Diabetes
Patients. The Journal of Immunology; 188(3):1325-1332.

[27] Huang YW, Liao YT, Chen W, Chen CL, Hu JT, Liu CJ, Lai MY, Chen PJ, Chen DS, Yang SS, Kao JH, (2010): Vitamin D receptor gene polymorphisms and distinct clinical phenotypes of hepatitis B carriers in Taiwan. Genes and Immunity; 11(1):87-93.

[28] Reimers LL, Crew KD, Bradshaw PT, Santella RM, Steck SE, Sirosh I, Terry MB, Hershman DL, Shane E, Cremers S, Dworakowski E, (2015): Vitamin DRelated Gene Polymorphisms, Plasma 25Hydroxyvitamin D, and Breast Cancer Risk. Cancer Causes \& Control; 26(2):187-203. 
Table 1: primers sequnces

\begin{tabular}{|ll|}
\hline Primers sequence & Nucleotide sequence \\
\hline \hline Apa - A & 5' - GTG GGA TTG AGC AGT GAG GT - 3' \\
Apa - a & 5' - GTG GGA TTG AGC AGT GAG GG - 3' \\
Taq - T & 5' - CGG TCC TGG ATG GCC TCA - 3' \\
Taq - t & 5' - CGG TCC TGG ATG GCC TCG - 3' \\
\hline
\end{tabular}

Table 2: Demographic characteristics and hematological parameters of Patients and control subjects enrolled to the study

\begin{tabular}{|c|c|c|c|c|c|}
\hline & & $\begin{array}{c}\text { Control } \\
(n=49)\end{array}$ & $\begin{array}{c}\text { Patients } \\
(n=81)\end{array}$ & Test Statistic & P-value \\
\hline \multirow[t]{2}{*}{ Gender } & $\mathbf{F}$ & $18(36.7 \%)$ & $53(65.4 \%)$ & \multirow[t]{2}{*}{$\chi^{2}=10.14$} & \multirow[t]{2}{*}{$0.001^{*}$} \\
\hline & $\mathbf{M}$ & $31(63.3 \%)$ & $28(34.6 \%)$ & & \\
\hline \multicolumn{2}{|c|}{$\begin{array}{c}\text { Age } \\
\text { (Year) }\end{array}$} & $\begin{array}{c}39.35 \pm 15.59 \\
(12-65)\end{array}$ & $\begin{array}{c}34.86 \pm 20.34 \\
(0.03-75)\end{array}$ & $\mathrm{t}=1.29$ & 0.199 \\
\hline \multicolumn{2}{|c|}{ Hb\% } & $\begin{array}{c}13.47 \pm 0.86 \\
(11-16.1)\end{array}$ & $\begin{array}{c}8.3 \pm 1.71 \\
(3.5-11)\end{array}$ & $\mathrm{t}=22.47^{* *}$ & $<0.0001$ \\
\hline \multicolumn{2}{|c|}{ Iron Conc. } & $\begin{array}{c}30.36 \pm 4.96 \\
(22.9-53)\end{array}$ & $\begin{array}{c}22.1 \pm 5.25 \\
(13.2-50.8)\end{array}$ & $\mathrm{t}=8.85^{* *}$ & $<0.0001$ \\
\hline \multicolumn{2}{|c|}{ Ferritin conc. } & $\begin{array}{c}169.85 \pm 174.19 \\
(14.72-598.1)\end{array}$ & $\begin{array}{c}140.86 \pm 221.07 \\
(1.85-920.77)\end{array}$ & $\mathrm{t}=0.78^{\mathrm{NS}}$ & 0.435 \\
\hline
\end{tabular}

$*$ : significant difference $(\mathrm{P}<0.05)$

** : highly significant difference $(\mathrm{P}<0.01)$

NS: non-significant difference

Table 3 Distribution of ApaI and TaqI polymorphisms among cases and controls

\begin{tabular}{c|c|c|c|c}
\hline SNP & Genotype/Allele & Cases $\boldsymbol{n}(\boldsymbol{\%})$ & Controls $\boldsymbol{n}(\boldsymbol{\%})$ & p-Value \\
\hline ApaI & $\mathrm{GG}$ & $29(35.8 \%)$ & $20(40.8 \%)$ & \\
\hline & $\mathrm{GT}$ & $43(53.1 \%)$ & $26(53.1 \%)$ & \\
\hline & $\mathrm{TT}$ & $9(11.1 \%)$ & $3(6.1 \%)$ & 0.375 \\
\hline$\chi^{2}$ & $\mathrm{G}$ & $101(62.4 \%)$ & $66(67.4 \%)$ & 0.415 \\
\hline Hardy-Weinberg p & $\mathrm{T}$ & $61(37.7 \%)$ & $32(32.7 \%)$ & \\
\hline Value & & 1.38 & 2.09 & \\
\hline TaqI & & 0.240 & 0.148 & \\
\hline$\chi^{2}$ & $\mathrm{TT}$ & $12(14.8 \%)$ & $3(6.1 \%)$ & \\
\hline & $\mathrm{TC}$ & $60(74.1 \%)$ & $45(91.8 \%)$ & \\
\hline CC & $9(11.1 \%)$ & $1(2.0 \%)$ & \\
\hline Value & $\mathrm{T}$ & $84(51.9 \%)$ & $51(52.0 \%)$ & \\
\hline & $\mathrm{C}$ & $78(48.2 \%)$ & $47(47.9 \%)$ & \\
\hline
\end{tabular}


Table 4 Association of genotypes at ApaI and TaqI polymorphisms with hematological parameters

\begin{tabular}{c|c|c|c}
\hline & Hb\% & Iron Conc. & Ferritin conc. \\
\hline ApaI & & & \\
\hline GG $(\mathrm{n}=49)$ & $10.32 \pm 0.43$ & $25.71 \pm 0.95$ & $151.48 \pm 36.86$ \\
\hline GT $(\mathrm{n}=69)$ & $10.41 \pm 0.34$ & $25.29 \pm 0.82$ & $161.64 \pm 20.63$ \\
\hline TT(n=12) & $9.58 \pm 0.93$ & $23.00 \pm 1.22$ & $96.41 \pm 34.48$ \\
\hline F-value & 0.42 & 0.84 & 0.52 \\
\hline P-value & 0.66 & 0.435 & $119.25 \pm 170.46$ \\
\hline TaqI & & & $153.42 \pm 203.16$ \\
\hline TT $(n=15)$ & $9.76 \pm 2.71$ & $23.73 \pm 6.55$ & $183.49 \pm 272.12$ \\
\hline TC $(n=105)$ & $10.50 \pm 2.96$ & $25.48 \pm 6.15$ & 0.31 \\
\hline CC $(n=10)$ & $8.90 \pm 2.26$ & $25.01 \pm 9.96$ & 0.734 \\
\hline F-value & 1.67 & 0.47 & \\
\hline P-value & 0.193 & 0.624 & \\
\hline
\end{tabular}

Table 5 Association between genotype distributions at ApaI and TaqI VDR polymorphisms and Anemia under genetic models

\begin{tabular}{|c|c|c|c|c|c|c|}
\hline 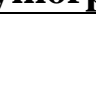 & Model & Genotype & $\begin{array}{c}\text { Control (\%) } \\
n=49\end{array}$ & $\begin{array}{c}\text { Cases }(\%) n \\
=81\end{array}$ & OR(95\%CI) & P-value \\
\hline \multirow[t]{8}{*}{ ApaI } & & & & & & 0.606 \\
\hline & Codominant & $\mathrm{GG}^{\mathrm{R}}$ & $20(40.8 \%)$ & $29(59.2 \%)$ & 1 & \\
\hline & & GT & $26(37.7 \%)$ & $43(62.3 \%)$ & $1.14(0.54-2.41)$ & 0.731 \\
\hline & & $\mathrm{TT}$ & $3(25.0 \%)$ & $9(75.0 \%)$ & $2.07(0.50-8.61)$ & 0.317 \\
\hline & Dominant & $\mathrm{GG}^{-G T^{R}}$ & $46(39.0 \%)$ & $72(61.0 \%)$ & 1 & \\
\hline & & $\mathrm{TT}$ & $3(25.0 \%)$ & $9(75.0 \%)$ & $1.92(0.49-7.45)$ & 0.348 \\
\hline & Recessive & $\mathrm{GG}^{\mathrm{R}}$ & $20(40.8 \%)$ & $29(59.2 \%)$ & 1 & \\
\hline & & GT -TT & $29(35.8 \%)$ & $52(64.2 \%)$ & $1.24(0.60-2.56)$ & 0.568 \\
\hline \multirow[t]{8}{*}{ TaqI } & & & & & & 0.063 \\
\hline & Codominant & $\mathrm{TT}^{\mathrm{R}}$ & $3(20.0 \%)$ & $12(80.0 \%)$ & 1 & \\
\hline & & $\mathrm{TC}$ & $45(42.9 \%)$ & $60(57.1 \%)$ & $0.33(0.09-1.25)$ & 0.104 \\
\hline & & $\mathrm{CC}$ & $1(10.0 \%)$ & $9(90.0 \%)$ & $2.25(0.20-25.37)$ & 0.512 \\
\hline & Dominant & TT-TC ${ }^{\mathrm{R}}$ & $48(40.0 \%)$ & $72(60.0 \%)$ & 1 & \\
\hline & & $\mathrm{CC}$ & $1(10.0 \%)$ & $9(90.0 \%)$ & $6(0.74-48.90)$ & 0.089 \\
\hline & Recessive & $\mathrm{TT}^{\mathrm{R}}$ & $3(20.0 \%)$ & $12(80.0 \%)$ & 1 & \\
\hline & & $\mathrm{TC}-\mathrm{CC}$ & $46(40.0 \%)$ & $69(60.0 \%)$ & $0.38(0.10-1.40)$ & 0.145 \\
\hline
\end{tabular}

$\mathrm{R}:$ Reference groups; OR: odds ratio; CI: confidence interval 
Table 6: correlation between clinical parameters

\begin{tabular}{|c|c|c|}
\hline & Control & Patient \\
\hline \multicolumn{3}{|l|}{ Hb iron } \\
\hline $\mathbf{R}$ & 0.019 & -0.18 \\
\hline P-value & 0.895 & 0.116 \\
\hline \multicolumn{3}{|l|}{ Hb Ferritin } \\
\hline $\mathbf{R}$ & -0.015 & $-0.267 *$ \\
\hline P-value & 0.916 & 0.018 \\
\hline \multicolumn{3}{|l|}{$\mathbf{F e} \sim$ Ferritin } \\
\hline $\mathbf{R}$ & 0.135 & -0.015 \\
\hline P-value & 0.354 & 0.897 \\
\hline
\end{tabular}

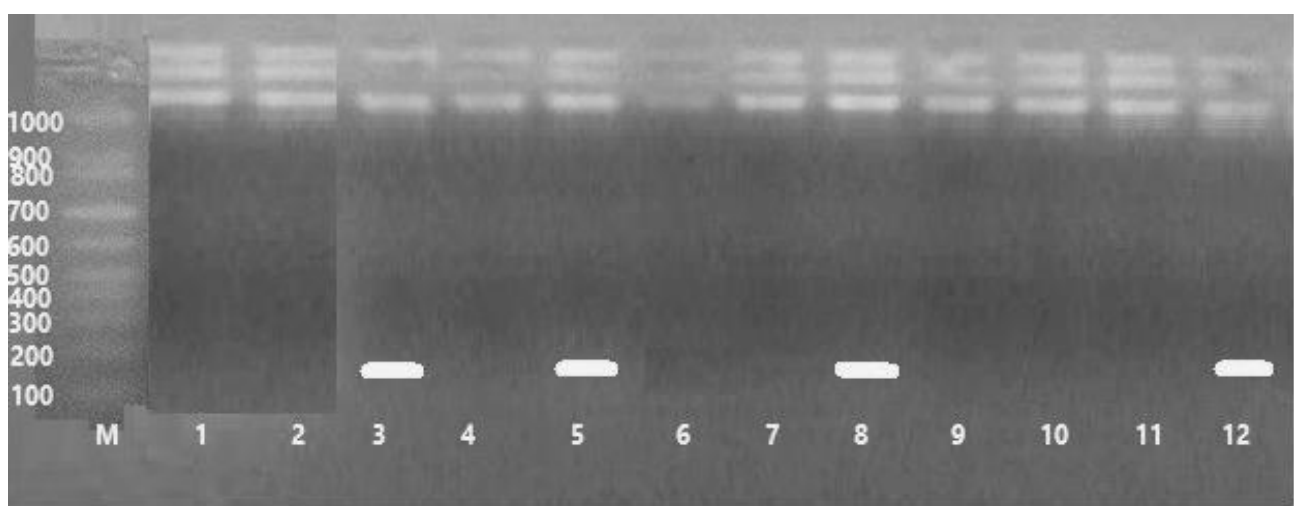

Fig (1): a representative agarose gel. The lanes 1-4 represent the four PCR reactions of $1^{\text {st }}$ sample. The lanes 5-8 are for $2^{\text {nd }}$ sample. The lanes 9-12 are for $3^{\text {rd }}$ sample. For the first sample, the band appears in the third reaction which means AAtt (homozygote haplotype). For the second sample, the bands appear in the first and fourth lanes which mean AaTt (heterozygote haplotype). For the third sample, the band appears in the $4^{\text {th }}$ lane which means aatt (homozygote haplotype). 